\title{
TOPICALITY OF TRADITIONAL SKILLS IN CONTEMPORARY CULTURAL ENVIRONMENT
}

\author{
Anete Karlsone \\ Institute of Latvian History, University of Latvia \\ e-mail:anete.karlsone@gmail.com
}

\begin{abstract}
The interest in intangible cultural heritage, proposed by UNESCO, continues to maintain its topicality in the community. Traditional skills and knowledge are part of the intangible cultural heritage. Nowadays, with a variety of information flows becoming more and more active, they continue to maintain their place in the society of Latvia.

The skills of using dyes present in plants for dyeing textiles (wool, linen, etc.) and other materials form one of the areas of Latvian, as well as Bulgarian, intangible cultural heritage.

The present article provides an insight into the current situation in Latvia regarding the use of plant dyes and the knowledge of the field. It is based on a study conducted in recent years with the aim to find out the motivation of people interested in research and use of the traditional knowledge, and its role in modern society.
\end{abstract}

Keywords: ethnology, intangible cultural heritage, plant dyes, traditional skills 


\section{Introduction}

Nowadays, with the increasing circulation of various kinds of information, the traditional skills and knowledge also continue to preserve their place in the life of the community. They are part of the intangible cultural heritage of humanity, which UNESCO has been focusing on in recent years. In 2003, the UNESCO Convention for the Safeguarding of the Intangible Cultural Heritage (ICH) was adopted. In turn, on December 1 2016, the Law of the ICH came into force in Latvia. According to its definition, the ICH also comprises traditional skills and knowledge. Part of them is the use of plant dyes.

In recent years, the public interest in dyeing with natural dyes has been growing in Latvia. Every year, dyeing workshops are held in different places of Latvia. There is also an active exchange of information on this topic on social networks (Facebook, etc.). Besides, several exhibitions have been devoted to natural dyes. From 25.01.2012 to 04.03.2012, for the first time, the travelling exhibition "Daba krāso" (Nature dyes) could be seen in the Latvian Museum of Nature. It gathered a very large number of visitors. Later, the exhibition was also displayed in different places outside Riga. In September and October 2017, another exhibition "Daba krāso - "Dzilna" auž" (Nature dyes - "Dzilna" weaves) could be visited in Limbaži. It presented the achievements of the weavers of Limbaži Folk Applied Arts Studio working with yarns dyed in plant dyes. There are other additional events where the interest in dyeing with natural dyes has been paid attention to.

Dye plants (as well as natural animal dyes) have always been and are still being studied in connection with the history of textile making technologies (including history of chemistry), the occupation of professional craftsmen, and, of course, the development of fashion. In this area, both highly-practical publications (Berger 2011; Bräuer 1989; Casselman 1993; Buchanan 1995; etc.), and also cultural and interdisciplinary studies (Cardon 2007; Kay-Williams 2013; Michel Pastoureau 2001, 2009, 2014, 2017; Chenciner 2004; etc.) can be found. The attention of the explorers of natural colourants is mainly focused on the economically significant natural dyes: the red colour from Rubia tinctorum L. and Galium L., as well as from cochineals Dactylopius coccus Costa and brazilwood Paubrasilia echinata (Lam.) Gagnon, the blue colour from woad Isatis tinctoria L. and indigofera Indigofera tinctorum L. etc. 
There are comparatively fewer studies of the use of plant dyes as a traditional skill, the environment of application of which historically is generally related to the peasant or folk lifestyle (Fraser 1996; Maxia et al. 2013; Mayolo 1989; Böhmer 2002; etc.). Such studies are possible in those regions where the type of subsistence economy was preserved for a relatively long period of time and where the provision of clothing was carried out within each family. Thus, the inherited knowledge and its use were preserved there for a longer time.

The only book in Latvian on the possibilities of use of natural dyes is the practically oriented edition of 1990 - "Krāsošana ar augu krāsvielām" (Dyeing with Plant Dyes) (Madre 1990). Ilga Madre, the author of this edition, was a handicraft master, at that time a socially active dyer with plant dyes, who also participated in the collection of ethnographic materials.

Although in the public events held in Latvia today, one could observe interest in this area of traditional skills, there is little scientific research. So far, several texts have been published by the author of this article on the sources of dye plant research (Karlsone 2014, 2016a, 2016b, 2017, 2018). This article is a continuation of the ongoing research and gives an insight into the current situation of practical use of plant dyes and the knowledge of this field. Its purpose is to explain what the motivation of the people interested to learn and apply traditional knowledge is, how they are inherited, what their content is, what is the level of existence of the use of plant dyes tradition in modern times in Latvia, and so on.

In the summer season of 2016 and 2017, a survey was conducted among the people interested in this field. Most of them were participants of dyeing workshops. As the survey was conducted in a specialised interest group, its results do not fit into statistic indicators of developments in the whole Latvian society. As it is planned to continue the survey, the data obtained are considered as initial information that may change conducting further research.

\section{Survey on Dyeing with Plant Dyes: Characteristics of Participants}

The questionnaire "Pètījums par krāsaugu lietojuma tradīciju" (Study on the Tradition of the Use of Plant Dyes) comprised twelve questions. They record both the minimal personal information about the speaker and issues related to various aspects of the use of plant dyes. None of the questions offer 
multiple choice options. Consequently, the results highlighted several groups of responses that were not previously foreseen.

If the dyeing workshops took place in the open-air territory of the museum, both the participants of the workshop, and also the random visitors of the event were asked to fill in the questionnaires. Participants of the dyeing workshops are only part of the people actively seeking for new information in this field. Due to various circumstances not all the participants of the workshops filled in the questionnaires. The total number of questionnaires analysed currently is 94 . According to the results, it is possible to determine trends in the development of the tradition of using dye plants in Latvia nowadays.

Those interested in dyeing with plant dyes and taking part in dyeing workshops consist of mostly women. There were only 6 men - both active dyers and casual observers. Nevertheless, in content and character their responses fitted in the total set of the answers, without any special difference from others.

Summarizing data on the age of respondents, it is found that most of them are in the range of 40 to 60 years of age. However, the youngest were only 12 and 15 years old, but the oldest -79 . Respectively, the respondents, in most cases, were born from the late 1950s to the 1980s.

Although questions about the level of education and place of residence were not asked, the observations during conversations show that both rural and urban residents are interested in dyeing with plant dyes, as well as people with higher and general secondary education.

One question in the questionnaire was about the level of previous knowledge about dyeing with plant dyes. In some cases, the respondents answering this question gave two answers. For example, 'there is no prior knowledge, only a little bit read about it in theory' (questionnaire No. 7, a woman born in 1962). As a result, the total number of responses is higher than the number of respondents.

More than $1 / 3$ of the respondents, in this case, 37 , answered negatively regarding previous knowledge about the use of plant dyes. Still, $1 / 4$ of these responses (nine cases), indicated that there is no prior knowledge with the addition that the only contact with plant dyes is the dyeing of eggs for Easter. So, to some extent, there is some experience in the use of plant dyes, if not in the dyeing of textiles. 
Personal experience and practice is the second most commonly mentioned type (twenty-five cases) in which knowledge about dyeing with plant dyes has been acquired. Some respondents had only had isolated attempts, the results of which were not always satisfying. By contrast, others, who were independent practicing dyers, have accumulated varying degrees of experience. The participants of this group of respondents take part in the dyeing workshop to deepen knowledge and to clarify problematic issues.

The third group of responses (twenty-three cases) regarding background knowledge suggests that knowledge about dyeing with plants was obtained through observation. These are the respondents' childhood memories, when their mother, grandmother or some other relative, dyed yarns with plant dyes; or observations participating in dyeing workshops when plant dyes are used by craftsmen.

In the fourth place, according to the number of being mentioned (eighteen cases), the answer is that the knowledge is purely theoretical because dyeing with plant dyes has only been read about or heard about from others. In this case, too, the level of theoretical knowledge could be very different - from very general information to very specific knowledge, which, due to different circumstances, by then had not been used in practice.

\section{Dyeing with Plant Dyes: Motivation of Interest}

An essential question of the research carried out on the use of plant dyes nowadays is that of motivation of interest. The respondents, if they wished, were free to specify several motives. In the first place, as a motivation that makes dyeing with plant dyes attractive, the close link of this activity with nature stands out. In this case, it is not analysed how substantiated are the claims in some of the replies regarding the absolutely 'ecological' nature of this field. Still, in general, this group of responses undoubtedly shows the growing popularity of the 'green lifestyle' in today's society. The fact that dye plants, as a renewable natural resource that is the basis for the development of sustainable economy, is recognised also by modern day researchers of colourants in other parts of Europe (Bechtold \& Mussak 2009: XX).

In the second place of motivation, with thirty-three answers, comes the set of responses that could be denoted as 'curiosity'. This group contains answers 
that mention this activity as simply interesting, as well as indications that by mastering dyeing with plant dyes it is possible to further educate oneself.

In the third place, with twenty-four answers, comes the set which emphasises that the interest is based on the cultural-historical aspect - the fact that dyeing with plant dyes is a traditional skill that has been practiced in the previous centuries. So, the historical aspect, the fact that it is 'the skill that the ancestors knew' (question No. 50, a woman, 1964) is relevant to about $1 / 4$ of the respondents. This aspect is relevant mainly for people aged 40 to 55 and also for some 58, 61 and 66 years old respondents. This motivation was not mentioned in other age groups.

The fourth set of answers (twenty-two responses) is the artistic quality of colours obtained from plant dyes: tone nuance, pleasant, harmonious tones, from which it is easy to create colour compositions. Also, such descriptions as 'colour tones are unique, warm, appealing to Latvian mentality' are used (question No. 64, a woman, 1947), as well as simply 'natural colours' (question No. 35, a woman, 1973; No. 36, a woman, 1948). The respondents in this group represent all age groups, including the girls born in 2000, and the oldest respondent in this survey, a woman born in 1938. The view expressed has got both a practical justification and it is possible to discern in it a reference to the interwar period rhetoric about the use of plant dyes occurring in public space in Latvia. The artistic qualities resulting from the use of plant dyes were especially emphasised in the introductory part of the articles published in Latvian press in the ' 30 s and ' 40 s of the $20^{\text {th }}$ century (Liepina A. 1931; Niedra 1938; Liepina M. 1940; etc.). This view also continued to exist later in the education of handicraftsmen.

The fifth place (fourteen replies)contains answers in which the substantiation for the motivation of interest in dyeing with plant dyes is the creativity, a qualitative characteristic of this field, the possibility to experiment, not always receiving the expected result. It seems fascinating and interesting, attracts to this activity.

In six responses, alongside other motives, the economic benefit was mentioned. Plant dyes existing in nature are a resource relatively easy to access and it does not require great expenses.

Also, only in some responses, the motivation for person's interest in dyeing with plant dyes was to practise handicrafts. Alternatively, some people 
considered that yarns dyed like that were part of the so-called archaeological costume (imitation of the costumes of the $9^{\text {th }}-12^{\text {th }}$ centuries) or the process of creating an ethnographic costume. The last set of answers is related to the activities which, in preparation for the centenary of the State of Latvia, have been prompted by the Latvian National Centre for Culture with the common motto: 'Katram savu tautastērpu!' (A national costume for everyone). In recent years, they have gained popularity in a large part of the society of Latvia, and many women, but not only - also men, want to obtain their own national costumes. For some of them it seems very important that the yarn for the 'ancient' outfits should be dyed in accordance with the old technologies, which would thus give the costume a greater sense of 'authenticity'.

\section{The Type of Dissemination of Information}

The questionnaire also contains a question about the source of information from which the respondent has acquired knowledge on the use of dye plants. It is interesting, that even part of those respondents, who previously said they had no background knowledge, have answered this question. In the first place with fifty-two answers is the acquisition of information from other dyers or the work of a particular craftsman. Twenty-five answers state that the information was obtained from relatives of previous generations: mother, aunt or, more often, grandmother. So, to a large extent, the transfer of traditional knowledge from generation to generation continues to exist in an oral form or through direct observation. However, beside the inheritance of information in the circle of relatives, its circulation among people in their interest groups also exists. The answers of the respondents also mention five folk applied arts studios, the participants of which are currently actively using plant dyes in Latvia. The number of handicraft groups which use plant dyes is larger, as only a small part of the Latvian handicraftsmen participated in the survey.

The second most important source from which knowledge about the use of dye plants can be obtained is specialised literature (thirty-six answers). It includes both the only book on dyeing with plant dyes published in Latvian so far (Madre 1990) and the publications in mass media. Sometimes, the respondents mentioned this book inaccurately, without knowing the author, the exact title and time of publication. Since the book was very popular at the time, it can 
still be found in the bookshelves of many families, therefore it can be specified quite easily. The book of I. Madre has been mentioned in 13 responses, which makes up $1 / 3$ of the answers of this group.

Only in some cases the names of publications are specified, and they are both interwar period women's magazines such as 'Zeltene' and 'Atpūta', as well as the handicrafts attachments of the magazine 'Padomju Latvijas Sieviete'. If in the columns of the magazine 'Zeltene' several articles on dyeing with plant dyes can be found (Retels 1927; Liepina 1931; Niedre 1931; Ķengis 1934; Niedra 1938; etc.),in the magazine 'Atpūta, there have been only two of them (Pāvuliṇa 1935; Fišers 1940). Many more articles on this topic have been published in such publications as 'Latvijas Saule,' 'Sievietes Pasaule,' 'Zemkopju Saule,' 'Mana Māja,' etc. However, especially 'Zeltene' and 'Atpūta' as very popular publications could be more closely associated with the inter-war period publications containing a lot of useful information for the household. This could have been the reason why in the memory of people these publications especially are associated with information about dye plants.

During the Soviet period, the only general-purpose women`s magazine, the attachment of which also contained practical information for handicrafts, was 'Padomju Latvijas Sieviete.' This publication typically gives descriptions for weaving, knitting, clothing cut-outs as well as cooking recipes and practical tips for everyday household matters. Articles on dyeing with plant dyes can only be found in five attachments of this magazine (Madre \& Ošina 1979; Skujiņa 1980; Madre 1984). Most likely these are the articles by I. Madre that have remained in the memory of people, because in the publication of Emma Skujina, which is the answer to readers' questions, more information is included about the effect of plant dyes on various textile fibres. In contrast, the information given by I. Madre is similar to that provided in her later book on dyeing with plant dyes.

The other ways of gathering information indicated in the questionnaires are the Internet and television. The Internet as a resource of information about dyeing with plant dyes is becoming increasingly popular in recent years. Specialised companies of plant dye users and distributors operate in different countries of the world, various groups and individual conversation sites are available on social networks. Among dyers, the most popular are the web pages where one can not only buy natural dyes, mordants, etc., but also get acquainted with educational information on dye plants and the process of dyeing, for example, 
www.wildcolours.co.uk. But television nowadays is a rather inadequate source of information on using plant dyes. There it may be possible find some information about public activities in this field that would help to acquire dyeing skills only indirectly. In the 1980s, however, there were broadcasts on Latvian television where I. Madre showed and explained the process of dyeing with dye plants in great detail. The broadcasts of this time are probably reflected in the respondents' answers. Also the answers to other questions reflect the activities of I. Madre. Several dyers have indicated that they have worked with plant dyes about twenty or thirty years ago. It dates back to the '70s and ' $80 \mathrm{~s}$ of the $20^{\text {th }}$ century, which corresponds to the time of I. Madre's activities. Her active work led to a growing interest in dyeing with plant dyes and a desire to try it out yourself.

The knowledge acquired in educational establishments has also been mentioned as a source of information on dyeing with plant dyes. Respondents have named both secondary specialised schools such as Riga Applied Arts Secondary School, Smiltene Agricultural School, etc., and higher educational establishments - the Faculty of Home Economics of the University of Latvia [now Faculty of Pedagogy and Home Economics], the Faculty of Textile Materials Design and Technology of Riga Technical University, and the Latvian Academy of Arts. Within the framework of the course in home economics or the acquisition of textile arts, in Soviet times and in some places even today, students are introduced to the use of natural dyes.

As a little surprise in the answers regarding the sources of information, folklore, in particular - the Latvian folk songs, was mentioned. Some dozens of Latvian folk songs, which constitute only a tiny part of the very large collection of our folklore, however, also reflect the use of several dye plants. Additionally, in 2012, a CD of folklore recordings together with a small booklet on dyeing of yarn and fabrics with plant dyes was released, called "Saviešu mēlı̌šana" (Dumpe et al. 2012).

\section{Dye Plants and the Process of Dyeing}

The respondents were asked to name the dye plants they knew, even if they themselves had not used them. Given that about one third of the respondents had acknowledged that they did not have preliminary knowledge of dyeing 
with dyestuffs, surprisingly, only three people admitted that they knew no dye plants at all. Many of them could name three or four of them. Those who named six, seven or more dye plants, already possessed real dyeing experience that was revealed while working together. These respondents did not mention all the dye plants they knew, but only the most commonly used ones. Among the respondents, there were also those who named ten, eleven, twelve, sixteen, seventeen and eighteen dye plants.

In total, 76 dye plants and other natural colourants, such as cochineals (D. coccus) and extracts of colour pigments - indigo and purple - were named. 44 of them were mentioned only one or two times. Cinnamon (Cinnamomum spp.) and tumeric (Curcuma longa L.) have also been used as colourants. Among the plants named, there were those recorded in ethnographic sources as early as the end of the $19^{\text {th }}$ century, as well as those used for dyeing only starting from the second half of the $20^{\text {th }}$ century. More than ten times the plants were named in a way that can be botanically specified as: Alnus L., Hypericum L., Betula peldula Roth., Anthemis tinctoria L., Beta esculenta L., Allium cepa L., I. tinctorum L., Chamomilla recutita (L.) Rauschert, Galium L., Quercus robur L. and Vaccinium myrtillus L.

The question about the mordants used in the dyeing process was answered by twenty-nine respondents. They named both naturally formed substances such as urine, ash (lye obtained from ash), salt, iron rust water, beer, sour apple juice, acid birch juice, etc., and synthesised chemicals: alum, tin salt, iron sulphate, copper sulphate, tartar, chromic bichromate, vinegar, etc. This suggests that both ancient and contemporary dyeing methods are used, but the use of chemical mordants predominates.

As the answers to some questions were duplicated, the formulation of some questions should possibly be changed. It is intended to continue the study in the coming season and beyond.

\section{Conclusions}

Nowadays, in Latvia, a significant place in acquisition of the traditional skill the use of dye plants - in addition to the direct observation of the work of masters and the inheritance within the family, is obtaining information from 
publications in the Latvian language. International information available via the Internet occupies a relatively small place.

The main motivation for the interest in dyeing with plant dyes includes the environmental considerations and the fact that this field is not well-known in the common information space. It offers new, exciting information, an opportunity for broadening one's knowledge. In addition to these motives, historical and cultural, and creatively artistic motivation are also very significant. The fact, that dyeing with plant dyestuffs is part of the Latvian traditional cultural heritage, is important for a relatively large part of the people interested in this field.

The knowledge about dye plants is generally quite deep, which is evidenced by the significant numbers of dye plants named, and the fact, that those people, who believed they had no knowledge and experience in the use of plant dyes, still possessed some information about them. The tradition of using some dye plants for Easter egg dyeing that is still being actively practiced in Latvia also helps to maintain the level of this knowledge.

The range of natural dyes used for textiles varies over time. People use the available information creatively and experiment freely. It shows that the tradition of the use of plant dyes among the people who are interested is still alive. It is inherited and continues to develop.

\section{Acknowledgements}

The article has been prepared in the scope of the Latvian State research program Letonika (No. ZD2015/AZ85).

Survey data are used for research purposes only and only summarized and anonymous information is published.

\section{References}

Bechtold, Thomas \& Mussak, Rita (ed.) 2009. Handbook of Natural Colorants. Chichester: John Wiley \& Sons.

Berger, Dorit 2011. Färben mit Pflanzen: Färbenpflanzen. Rezepte. Anwendungen [Dyeing with Plants: Staining Plants. Recipes. Applications]. Stauen bei Freiburg: Ökobuch. 
Böhmer, Harald 2002. Koekboya. Natural Dyes and Textiles: A Colour Jorney from Turkey to India and Beyond. Gandrekesee: REMHÖB.

Bräuer, Barbara 1989. Textilfärben für jedermann [Textile Dyeing for Everyone]. Leipzig: Fachbuchverlag.

Buchanan, Rita 1995. A Dyers garden: From Plant to Pot. Growing Dyes from Natural Fibres. Loveland: Interweave Press.

Cardon, Dominique 2007. Natural Dyes: Sources, Tradition, Technology and Science. London: Archetype Publications.

Casselman, Karen Leigh 1993. Craft of the Dyer: Colour from Plants and Lichens. New York: Dover Publikations.

Chenciner, Robert 2004. Madder Red: A History of Luxury and Trade. London: Taylor \& Francis.

Dumpe, Baiba et al. 2012. Saviešu mēḷšana [Chats of the Saviesi and Dyeing with Woad]. [Riga]: Lauska.

Fišers, Georgs 1940. Krāsošana ar stādu vielām [Dyeing with Plant Substances]. Atpūta, Vol. 805, p. 18.

Fraser, Jean 1996. Traditional Scottish Dye. Edinburgh: Canongate.

Karlsone, Anete 2014. Nemateriālais kultūras mantojums: krāsaugu izmantojuma tradīcijas atspoguḷojums dažādos vēstures avotos [Intangible Cultural Heritage: The Reflection of Use of Colouring Plants in Different Historical Sources]. In: I. Saleniece (ed.) Vēsture: Avoti un cilvēki. History: Sources and People, Vol. XVII. Daugavpils: Saule, pp. 169-176. Available at https://du.lv/wp-content/ uploads/2015/12/Vesture_XVII.pdf, last accessed on 24.01.2019.

Karlsone, Anete 2016a. Krāsaugu lietojuma tradīcijas atspoguḷojums latviešu preses izdevumos (19. gadsimta beigas - 1940. gadi) [Reflection of the Tradition of the Use of Colouring Plants in Latvian Press Publications (End of $19^{\text {th }}$ Century 1940s)]. In: I. Saleniece (ed.) Vēsture: Avoti un cilvēki. History: Sources and People, Vol. XIX. Daugavpils: Saule, pp. 125-131. Available at https:/du.lv/wp-content/ uploads/2016/01/Vesture_XIX_2016_DRUKA.pdf, last acessed on 24.01.2019.

Karlsone, Anete 2016b. Rakstītie avoti par krāsaugu lietojuma tradīciju Latvijas teritorijā. 19. gs. beigas - 1944. gads [The Written Sources on the Tradition of Use of Plant Dyestuffs on the Territory of Latvia. The End of the XIX Century - the Year 1944]. Arheologija un Etnogräfija, Vol. XXIX. Rīga: Zinātne, pp. 193-204.

Karlsone, Anete 2017. Baltvāciete Marta Bīlenšteina un viṇas pētījums par latviešu tradicionālo kultūras mantojumu [The Baltic German Martha Bielenstein and Her Research into the Latvian Traditional Culture Heritage]. In: I. Saleiece (ed.) Vēsture: Avoti un cilvēki. History: Sources and People, Vol. XX. Daugavpils: 
Saule, pp. 167-173. Available at https://du.lv/wp-content/uploads/2016/01/ Vesture_XX_2017.pdf, last accessed on 29.03.2018.

Karlsone, Anete 2018. LU LVI Etnogrāfisko materiālu krātuvē esošās ziṇas par krāsaugu lietojumu Latvijā [Information about Natural Dyeing in the Repository of Ethnographic Material of the Institute of Latvian History]. In: I. Saleniece (ed.) Vēsture: avoti un cilvēki. History: Sources and People, Vol. XXI. Daugavpils: Saule, pp. 202-208. Available at https://du.lv/wp-content/uploads/2018/01/ Vesture_XXI_2018_internets.pdf, last accessed on 29.03.2018.

Kay-Williams, Susan 2013. The Story of Colour in Textiles. London: Bloomsbury Publishing PLC.

Ķeņgis, Marija 1934. Dziju un audumu krāsošana ar indigo [Dyeing of Yarn and Fabrics with Indigo]. Zeltene, Vol. 14, p. 15.

Liepiṇa, Aleksandra 1931. Krāsošana stādu vielām [Dyeing with Plant Substances]. Zeltene, Vol. 4, p. 26; Vol. 5, p. 16; Vol. 6, p. 17; Vol. 7, p. 26.

Liepiṇa, Milda 1940. Vāksim krāsaugus [We Collect Dyeing Plants]. Sievietes Pasaule, Vol. 14, p. 28.

Madre, Ilga \& Ošina, I. 1979. Augu krāsvielas [Plant Dyestuff]. Padomju Latvijas Sieviete. Pielikums, Vol. 6.

Madre, Ilga 1984. Krāsošana ar augu krāsvielām [Dyeing with Plant Dyes]. Padomju Latvijas Sieviete. Pielikums. Vol. 7-9.

Madre, Ilga 1990. Krāsošana ar augu krāsvielām [Dyeing with Plant Dyes]. Rīga: Avots. Maxia, Andrea et al. 2013. Dye plants: Natural resources from traditional botanical knowledge of Sardinia Island, Italy. Indian Jornal of Traditional Knowledge, Vol. 12 (4), pp. 651-656.

Mayolo de, Kay K. Antúnez 1989. Peruvian Natural Dye Plants. Economic Botany, Vol. 43 (2), pp. 181-191. Available at http://www.jstor.org/stable/4255151, last accessed on 12.11.2017.

Niedra, M. 1938. Krāsosim ar augu krāsām [Let Dye with Plant Dyes]. Zeltene, Vol. 12, pp. 21-22; Vol. 13, p. 25.

Niedre, Jānis 1931. Seno latviešu krāsas un krāsošana stādvielām [Ancient Latvian Colours and Dyeing with Plants]. Zeltene, Vol. 21, pp. 16-18; Vol. 22, pp. 14-15; Vol. 23, pp. 17-19; Vol. 24, p. 20.

Pastoureau, Michel 2001. Blue: The History of a Color. New Jersey, US: Princeton University Press.

Pastoureau, Michel 2009. Black: The History of a Color. New Jersey, US: Princeton University Press.

Pastoureau, Michel 2014. Green: The History of a Color. New Jersey, US: Princeton University Press. 
Anete Karlsone

Pastoureau, Michel 2017. Red: The History of a Color. New Jersey, US: Princeton University Press.

Pāvuliṇa, Kristīne 1935. Krāsosim dabiskām krāsām! [Let Dye with Natural Dyes!] Atpūta, Vol. 548, p. 19.

Retels, P. 1927. Latvijas krāsojošie augi [Latvian Dyeing Plants]. Zeltene, Vol. 12, p. 25. Skujiņa, Emma 1980. Novirzes krāsošanā [Errors in dyeing]. Padomju Latvijas Sieviete. Pielikums, Vol. 5. 